\title{
Breast Cancer in Men: Characteristics Epidemiological, Clinicopathological and Therapeutic
}

\author{
Ahmadaye Ibrahim Khalil ${ }^{1 *}$, Houriya Mestaghanmi1, Fadwa Qachach ${ }^{2}$, Rachid Saile ${ }^{3}$, \\ Karima Bendahhou ${ }^{4}$, Abdellatif Benider ${ }^{2}$
}

${ }^{1}$ Pathophysiology and Molecular Genetics Laboratory, Faculty of Sciences Ben M'Sik, University Hassan II Casablanca, Morocco

${ }^{2}$ Mohammed VI Center for Cancer Treatment, CHU IbnRochd Casablanca, Morocco

${ }^{3}$ Biology and Health Laboratory, Research Unit Associated to CNRST-URAC 34, Faculty of Sciences Ben M'Sik, University Hassan II

Casablanca, Morocco

${ }^{4}$ Cancer Registry of the Greater Casablanca, Morocco

Email: `brahimahmadaye@yahoo.fr

How to cite this paper: Khalil, A.I., Mestaghanmi, H., Qachach, F., Saile, R., Bendahhou, K. and Benider, A. (2016) Breast Cancer in Men: Characteristics Epidemiological, Clinicopathological and Therapeutic. Open Access Library Journal, 3: e3166.

http://dx.doi.org/10.4236/oalib.1103166

Received: October 24, 2016

Accepted: November 5, 2016

Published: November 10, 2016

Copyright (อ 2016 by authors and Open Access Library Inc.

This work is licensed under the Creative Commons Attribution International License (CC BY 4.0).

http://creativecommons.org/licenses/by/4.0/

\section{(c) (i) Open Access}

\begin{abstract}
Background: Breast cancer is the leading malignancy in women, but it is relatively rare in men, accounting for $1 \%$ of all breast cancers. In Morocco, its incidence is $0.8 /$ 100,000 in men. This condition epidemiology, therapeutic and prognostic remains unknown given the scarcity of reported series. The objective of this work is to identify the epidemiological, clinical, pathological and therapeutic of this cancer in men. Results: Six patients were diagnosed with breast cancer with a ratio of 6/1277 cases. The mean age of patients was $63.3 \pm 9.7$ ans; the most common histological type was invasive ductal carcinoma (83.3\%). The grade 2 SBR has a majority (66.7\%), while that of SBR 3 is less represented (33.3\%). A positive estrogen receptor $(66.7 \%$ of cases) and progesterone (50.0\% of cases) was noted. The HER2 receptor is overexpressed in $25 \%$ of cases. The treatment was essentially surgical (83.3\%). Additional treatment included adjuvant chemotherapy $(50.0 \%)$, radiotherapy $(50.0 \%)$ and hormonal therapy (16.7\%) was administered. Discussion/Conclusion: Breast cancer in men is rare and appears to have a very close clinical, histological characteristics and prognosis to those of elderly women. The diagnosis is usually late and tumors are treated in advanced stages. An improved prognosis requires better awareness for early detection.
\end{abstract}

\section{Subject Areas}

Oncology 


\section{Keywords}

Breast Cancer, Men, Epidemiology, Clinical, Therapeutic

\section{Introduction}

Breast cancer is the most common cancer in women in both the developed and developing countries.

However, this typically "female" disease can also affect males. Male breast cancer is a rare disease. It represents approximately $1 \%$ of breast cancers and $0.6 \%$ of the malignant disease in humans [1] [2]. Its incidence increases gradually, from $0.86 / 100,000$ to $1.06 / 100,000$ inhabitants in the last three decades [3].

In Morocco, according to the Cancer Register of the Region of Greater Casablanca (RCRC), its incidence is $0.8 / 100,000$ in men [4]. It is a disease diagnosed more often at an advanced stage, making prognosis worse [5]. The only way to study the characteristics of this disease in males is the retrospective analysis of several small series of patients over several years. Several risk factors have been implicated such as direct family history, some metabolic and endocrine disorders, particularly real or relative hyper-œstrogenism [6].

Breast cancer in men is a little known pathology of the public and the discovery of a breast lump in a man does not raise the same concern as in women. Most studies show a more advanced stage at diagnosis and a poorer prognosis in men [7] [8]. Treatment recommendations for breast cancer in men are extrapolated from those used for breast cancer in women. Men are treated as postmenopausal women. However, until now no study made on the male population showed the modalities of care in terms of affects survival [9] [10]. The objectives of this study are to investigate the epidemiological, clinical, histological, therapeutic and prognosis of breast cancer in men treated at the Mohammed VI center for the treatment of cancer.

\section{Patients and Methods}

\subsection{Type of Study}

This is a cross-sectional study at the Mohammed VI center for the treatment of cancers Hospital IBN ROCHD (One of the two major centers for the care and treatment of cancers in Morocco treating 3000 - 3500 cases of cancers including breast cancer represents $20 \%$ of cases and breast cancer in men is $0.4 \%$ of cases).

\subsection{Study Population}

We included in our study consecutively all cases of male breast cancer that has been treated at the Center from January first 2013 until 30 December 2014. Data collection was done retrospectively, from patient medical records.

The data collected focused on: 
- Socio-demographic data: Age at diagnosis, marital status, number of children and the concept of breast cancer family history.

- Clinical data: The stage at diagnosis, tumor size, lymph node involvement, distant metastasis, histological type, histological grade, laterality with quadrant or tumor region, the hormone receptor status, HER2 receptor (Human Epidermal growth factor) and proliferation index Ki-67.

- Therapeutic Data: Neoadjuvant chemotherapy, radiotherapy, adjuvant chemotherapy, hormone therapy and targeted therapy.

The variables studied were all well documented in all patients. Agreement of the ethics committee has been proven to this study. Data entry was conducted by Microsoft Office Excel (2007) and analysis of variables by the Epi Info software. The study association by crossing the variables between groups was evaluated by the test of chi-square. The test is considered significant when $\mathrm{p}<0.05$.

\section{Results}

\subsection{Epidemiological Aspects}

Between January 2013 to December 2014, six cases of male breast cancer have been supported in the Mohammed VI center for cancer treatment, CHU Ibn Rochd Casablanca. Epidemiological, clinical, histological and therapeutic patients are summarized in Table 1. The mean age at diagnosis was $63.3 \pm 9.7$ ans.

\subsection{Histopathological Aspects}

The most common histological type was invasive ductal carcinoma, it was observed in $83.3 \%$ of cases and invasive carcinoma in $16.7 \%$ of cases. Tumors were localized in $50 \%$ of cases. Lymph node involvement was described in $33.3 \%$ of cases. In our series, male breast cancer was high grade (grade II and III). The SBR grade II was found in $66.7 \%$ of cases and grade III in $33.3 \%$ of cases. Hormone receptor positivity was found to estrogen in $66.7 \%$ of cases and progesterone in $50.0 \%$ of cases. Overexpression of HER 2 was observed in $25.0 \%$ of cases over $66.7 \%$ of cases. The molecular profile of male breast cancer was essentially luminal; luminal A was found in $50.0 \%$ of cases while luminal B in $16.7 \%$ of cases.

\subsection{Treatment}

Out of all of our series, $83.3 \%$ of patients underwent mastectomy and one patient had not undergone any surgery after the diagnosis of ductal carcinoma by biopsy. Of all mastectomies, $50.0 \%$ of cases were associated with axillary dissection and $16.7 \%$ of cases a simple mastectomy. Chemotherapy was performed in $50.0 \%$ of cases. The average age of patients in our series who received adjuvant chemotherapy was $59.0 \pm 8.1$ years. The additional irradiation was performed in $50.0 \%$ of cases. Of all irradiated patients, $55.5 \%$ of cases had lymph node involvement. Only one case (16.7\%) had a tumor over 2 $\mathrm{cm}$ and $100 \%$ of the cases had grade II tumors (Table 1 ). 
Table 1. Epidemiological, clinical, histological and therapeutic features.

\begin{tabular}{|c|c|c|}
\hline Features & Number $(\mathrm{N}=6)$ & Percentage (\%) \\
\hline Average age & 63.3 years & \\
\hline Smoking & 2 & 33.3 \\
\hline Breast cancer antecedent & 0 & 0 \\
\hline \multicolumn{3}{|l|}{ BMI } \\
\hline$<25$ & 4 & 66.6 \\
\hline $25-30$ & 0 & 0 \\
\hline$>30$ & 1 & 16.6 \\
\hline NP & 1 & 16.6 \\
\hline \multicolumn{3}{|l|}{ Call sign } \\
\hline Nodule & 2 & 33.3 \\
\hline Isolated retraction & 1 & 16.6 \\
\hline Isolated flow & 1 & 16.6 \\
\hline Isolated ulceration & 2 & 33.3 \\
\hline \multicolumn{3}{|l|}{ TNM Stage } \\
\hline T0 & 0 & 0 \\
\hline $\mathrm{T} 1$ & 0 & 0 \\
\hline $\mathrm{T} 2$ & 4 & 66.6 \\
\hline $\mathrm{T} 3$ & 0 & 0 \\
\hline $\mathrm{T} 4$ & 2 & 33.3 \\
\hline No & 3 & 50.0 \\
\hline N1 & 1 & 16.6 \\
\hline $\mathrm{N} 2$ & 1 & 16.6 \\
\hline N3 & 1 & 16.6 \\
\hline M0 & 5 & 83.3 \\
\hline M1 & 1 & 16.6 \\
\hline \multicolumn{3}{|l|}{ SBR grade } \\
\hline SBR I & 0 & 0 \\
\hline SBR II & 4 & 66.6 \\
\hline SBR III & 2 & 33.3 \\
\hline \multicolumn{3}{|l|}{ Histological Type } \\
\hline infiltrating ductal carcinoma & 5 & 83.3 \\
\hline Invasive carcinoma & 1 & 16.6 \\
\hline invasive lobular carcinoma Treatment & 0 & 0 \\
\hline \multicolumn{3}{|l|}{ Treatment } \\
\hline Mastectomy & 2 & 33.3 \\
\hline lumpectomy & 3 & 50.0 \\
\hline No surgery & 1 & 16.6 \\
\hline Chemotherapy & 3 & 50.0 \\
\hline Hormonotherapy & 1 & 16.6 \\
\hline Radiotherapy & 3 & 50.0 \\
\hline
\end{tabular}

\section{Discussion}

\subsection{Epidemiology}

Breast cancer is a rare condition in men. It represents less than $1 \%$ of cancers in men and only $0.6 \%$ of all breast cancer [6] [9]. It is the first cancer in women with a rate of $23 \%$ and is the leading cause of female cancer mortality [1] [2] [3]. The incidence of breast cancer has been increasing in recent years. Moreover, Harlan et al., showed an 
increase in breast cancer incidence in men by 26\% between 1973 and 1998 in the United States [11]. The incidence of this cancer varies by country. This variation suggests the impact of the environment on the incidence [12]. This pathology appears 10 years later in men than in women, with an average age ranging between 59 and 66 years [3] [6] [8] [10] [13]. In our study, the mean age at diagnosis was 63 years, 5 years younger in literature but remains higher than in women.

\subsection{Risk Factor}

The etiology of breast cancer in men is not clearly established and the small number of cases does not allow the realization of a prospective study. However, some risk factors seem to be implicated.

Several studies have shown the involvement of direct family history of breast cancer [5] [7] [9] [10] and constitutional mutations of BRCA 1 and BRCA2 [14] [15]. The most frequent cases that were observed were related mutations of the BRCA2 gene [15].

The US network of cancer (National Comprehensive Cancer Network current) recommends providing education and encouragement to self-examination and conduct biannual clinical breast exams for men with gene mutations BRCA1 and BRCA2 [16]. This type of cancer could also have an endogenous cause, such as chronic conditions responsible for anti-androgenic or hyperprolactinémiants effects such as liver failure, diabetes, obesity and kidney failure. Hormonal imbalance such as real hyperoestrogenism or relative or abnormalities of metabolism and excretion of endogenous steroids can also affect.

Hyperoestrogenism could also have an exogenous origin, in connection with certain medications [17] [18]. Some authors observed a hormone-dependency with hormone receptor-positive in 65 to 90 cases depending on the series, those with estrogen in 65\% $86 \%$ of cases and those with progesterone in $65 \%-80 \%$ of cases [9] [13] [15] [19]. In our series, it was positive to estrogen in $66.6 \%$ of cases and progesterone in $50 \%$ of cases. Most authors have shown that adjuvant hormonal therapy improved the prognosis for survival and complete remission rate and recommend a systematic hormone therapy for all stages N1 and metastasis [6] [7] [8] [9] [13] [19].

In our series, $16.7 \%$ of cases had severe obesity. As in women, overweight and obesity are risk factors implicated in breast cancer. Similar results have been observed by several authors [20].

A second cancer may be associated with breast cancer in humans. Moreover, Cutuli and al., by conducting a multicenter study found the association with various cancers, anteriorly, synchronous or Metachronous [18]. Associated cancers are various such as prostate cancer, colorectal, bronchopulmonary, esophageal, or blood disorders [18] [21]. Moreover, Satram-Hoang and al., found on a series of 1921 men with breast cancer, 221 or $11.4 \%$ developed a second metachronous malignant tumor [21].

\subsection{Diagnosis}

Breast Cancer diagnosis in men is usually done at later stages and tumor size is often 
superior to breast tumors in women [16]. In our series, stage at diagnosis was mostly stage II and III and all cases had T2 or T4 tumors, averaging 23 to $30 \mathrm{~mm}$. Korde and al., have shown that tumor size in men is an average of $2.4 \mathrm{~cm}$ versus $2.2 \mathrm{~cm}$ in women [16]. Mammography and ultrasound are used to help diagnosis with the same criteria of malignancy in women. Male breast cancer screening cannot be considered. Moreover, Hines et al., in a retrospective study from 2001 to 2004, have found only $4 \%$ of suspect images, and only $1 \%$ of cancers identified by biopsy on 212 patients with a mammography [22]. These authors showed the futility of imagery in male breast cancer and the diagnosis is in most cases clinical [22].

\subsection{Histology}

In our series, invasive ductal carcinoma was found in $83.3 \%$ of cases, this is the most common histological type, as in women. Similar results have been observed by several authors [6] [9] [10] [13].

Breast cancer in men rarely presents lobular carcinoma, unlike women where it occupies the second histology after invasive ductal carcinoma.

Male Breast cancer is characterized by a high expression of hormone receptors. In our study, we found positive hormone receptors in $80.0 \%$ of cases to estrogen and $60 \%$ to progesterone. HER2 overexpression is less common; our study showed that $25.0 \%$ of cases showed that overexpression. However, Giordano and al., in their study reported HER2 overexpression in $37 \%$ of cases [23].

We also noticed that in our study tumors were of high histological grade, $66.7 \%$ of grade II and $33.3 \%$ of grade III. Our results confirm those of Oger and al., which showed a high grade (grade II and III) in $72.0 \%$ of cases of breast cancer in men [24].

\subsection{Treatment}

Breast cancer treatment in humans based on mastectomy associated with an ipsilateral axillary dissection [25]. While in women, the standard treatment is a conservative or radical surgery in healthy margins, coupled with an analysis of the sentinel node [26]. In our series, $83.3 \%$ of patients underwent a mastectomy and $50 \%$ an ipsilateral axillary dissection. Axillary lymph node involvement is important in men and has been observed in $50 \%-60 \%$ of cases by some authors [27]. Our study revealed a lymph node in $50 \%$ of cases.

Radical surgery is completed with adjuvant treatments. Adjuvant radiotherapy reduces the risk of local recurrence, but is controversial, as some studies have shown no benefit in overall survival [28]. In our study, the indication of the irradiation was applied in $50.0 \%$ of cases; similarly, for chemotherapy. In literature, its use is beneficial in younger patients with nodal involvement or in high-risk patients with poor prognostic factors, such as lack of expression of hormone receptors [29].

Hormone therapy has an important place in the adjuvant treatment of breast cancer, given the high frequency of hormone receptor positivity [6] [8] [15] [30] [31]. The reference molecule is tamoxifen. In our series, $16.7 \%$ of patients received hormone thera- 
py with tamoxifen. Furthermore, Ribeito and al., noted in a series of 38 cases, a decrease in the risk of recurrence and death, after hormone treatment of patients [32].

Like any other study our study has its strengths and its limitations. This study presents the place of status the breast cancer in men is a particular entity at the center, but the information is limited and relates only to breast cancer in men cases in the public sector consultant and does not concerncases treated privately.

\section{Conclusions}

Male breast cancer is a rare disease and has its own characteristics. Considering all these observed differences, we cannot consider it as comparable to that of women.

The particularity of breast cancer in men is in its discovery at a late stage and high hormone receptor positivity. Besides, diagnosis and screening are the most important points to be developed to improve the prognosis. A large prospective study would improve knowledge regarding both diagnostic and therapeutic.

\section{Author Contributions}

Ahmadaye Ibtrahim Khalil: data collection, data entry, data analysis, results interpretation, writing of the manuscript, Houriya Mestaghanmi: Data analysis, results interpretation, writing of the manuscript, Fadwa Qachach: interpretation of results, writing of the manuscript, Rachid Saile: interpretation of results, writing of the manuscript, Karima Bendahhou: data analysis, results interpretation, writing of the manuscript, Abdellatif Benider: therapeutic management of patients and the writing of the manuscript.

\section{References}

[1] Comet, B., Cutuli, B., Penault-Llorca, F., Bonneterre, J. and Belkacemi, Y. (2009) Male Breast Cancer: A Review. Bulletin Cancer, 96, 181-189.

[2] Giordano, S.H., Cohen, D.S., Buzdar, A.U., Perkins, G. and Hortobagyi, G.N. (2004) Breast Carcinoma in Men: A Population Based Study. Cancer, 101, 51-57. http://dx.doi.org/10.1002/cncr.20312

[3] Weiss, J.R., Moysich, K.B. and Swede, H. (2005) Epidemiology of Male Breast Cancer. Cancer Epidemiology, Biomarkers \& Prevention, 14, 20-26.

[4] Registre des cancers de la Region de Grand Casablanca (2005, 2006, 2007) édition 2012.

[5] Benchellal, Z., Wagner, A., Harchaoui, Y., Huten, N. and Body G. (2002) Cancer du sein chez l'homme : A propos de 19 cas. Annales de Chirurgie, 127, 619-623. http://dx.doi.org/10.1016/S0003-3944(02)00816-7

[6] Donegan, W.L., Redlich, P.N., Lang, P.J. and Gall, M.T. (1998) Carcinoma of the Breast in Males: A Multiinstitutional Survey. Cancer, 83, 498-509. http://dx.doi.org/10.1002/(SICI)1097-0142(19980801)83:3<498::AID-CNCR19>3.0.CO;2-R

[7] Goss, P.E., Reid, C., Pintilie, M., Lim, R. and Miller, N. (1999) Male Breast Carcinoma: A Review of 229 Patients Who Presented to the Princess Margaret Hospital during 40 Years: (1955-1996). Cancer, 85, 629-639.

http://dx.doi.org/10.1002/(SICI)1097-0142(19990201)85:3<629::AID-CNCR13>3.0.CO;2-V

[8] Wilsher, P.C., Leach, I.H. and Ellis, I.O. (1997) A Comparison Outcome of Male Breast 
Cancer with Female Breast Cancer. The American Journal of Surgery, 173, 185-188. http://dx.doi.org/10.1016/S0002-9610(97)89592-X

[9] Memon, M.A., and Donohue, J.H. (1997) Male Breast Cancer. British Journal of Surgery, 84, 433-435. http://dx.doi.org/10.1002/bjs.1800840402

[10] Jaiyesimi, A., Buzdar, A.U., Sahin, A.A. and Ross, M.A. (1992) Carcinoma of the Male Breast. Annals of Internal Medicine, 117, 771-777. http://dx.doi.org/10.7326/0003-4819-117-9-771

[11] Harlan, L.C., Zujewski, J.A., Goodman, M.T., Goodman, M.T. and Stevens, J.L. (2010 Breast Cancer in Men in the United States: A Population-Based Study of Diagnosis, Treatment, and Survival. Cancer, 116, 3558-3568. http://dx.doi.org/10.1002/cncr.25153

[12] Ndom, P., Um, G., Bell, E.M., Eloundou, A., Houssain, N.M. and Huo, D. (2012) AmetaAnalysis of Male Breast Cancer in Africa. Breast, 21, 237-241. http://dx.doi.org/10.1016/j.breast.2012.01.004

[13] El Hajjam, M., Khaiz, D., Benider, A., Lakhloufi, A., Abi, F., Kahlain, A., et al. (1995) Cancer du sein chez l'homme. À propos de 50 observations. Journal de Chirurgie, 132, 131 136.

[14] Storm, H.H. and Olsen, J. (1999) Risk of Breast Cancer in Offspring of Male Breast-Cancer Patients. Lancet, 353, 209. http://dx.doi.org/10.1016/S0140-6736(05)77219-6

[15] Fentiman, I.S., Fourquet, A. and Hortobagyi, G.N. (2006) Male Breast Cancer. Lancet, 367 595-604. http://dx.doi.org/10.1016/S0140-6736(06)68226-3

[16] Korde, L.A., Zujewski, J.A., Kamin, L., Giodano, S., Domchek, S. anderson, W.F., Bartlet, J.M., Gelmon, K., Nahleh, Z., Bergh, J., Cutuli, B., Pruneri, G., McCaskil-Stevens, W., Gralow, J., Hortobagyi, G. and Cardoso, F. (2010) Multidisciplinary Meeting on Male Breast Cancer: Summary and Research Recommendations. Journal of Clinical Oncology, 28, 2114-2122. http://dx.doi.org/10.1200/JCO.2009.25.5729

[17] Bezwoda, W.R., Hesdorffer, C., Dansey, R., De Moor, N., Derman, D.P. and Browde, S. (1987) Breast Cancer in Men. Clinical Features, Hormone Receptor Status, and Response to Therapy. Cancer, 60, 1337-1340. http://dx.doi.org/10.1002/1097-0142(19870915)60:6<1337::AID-CNCR2820600629>3.0.CO; 2-C

[18] Cutuli, B.F., Lacroze, M., Dilhuydy, J.M., Florentz, P., Velten, M., Allavena, C., De Lafontan, B., Resbeut, M., Campana, F., Graic, Y., et al. (1992) Breast Cancer in Men: Incidence and Types of Associated Previous Synchronous and Metachronous Cancers. Bull Cancer, 79, 689-696.

[19] Lenfant-Pejovic, M.H., Mlika-Cabanne, N., Bouchardy, C. and Auquier, A. (1990) Risk Factors for Male Breast Cancer: A Franco-Swiss Case-Control Study. International Journal of Cancer, 45, 661-665. http://dx.doi.org/10.1002/ijc.2910450415

[20] Casagrande, J.T., Hanisch, R., Pike, M.C., Ross, R.K., Brown, J.B. and Henderson B.E. (1988) A Case-Control Study of Male Breast Cancer. Cancer Research, 48, 1326-1330.

[21] Satram-Hoang, S., Ziogas, A. and Anton-Culver, H. (2007) Risk of Second Primary Cancer in Men with Breast Cancer. Breast Cancer Research, 9, R10. http://dx.doi.org/10.1186/bcr1643

[22] Hines, S.L., Tan, W.W., Yasrebi, M., DePeri, E.R. and Perez, E.A. (2007) The Role of Mammography in Male Patients with Breast Symptoms. Mayo Clinic Proceedings, 82, 297300. http://dx.doi.org/10.1016/S0025-6196(11)61025-2

[23] Giordano, S.H., Valero, V., Buzdar, A.U. and Hortobagyi, G.N. (2002) Efficacy of Anastrozole in Male Breast Cancer. American Journal of Clinical Oncology, 25, 235-237. 
http://dx.doi.org/10.1097/00000421-200206000-00006

[24] Oger, A.-S., Boukerrou, M., Cutuli, B., Campion, L., Rousseau, E., Bussières, E., Raro, P. and Classe, J.-M. (2015) Le cancer du sein chez l'homme: approche épidémiologique, diagnostique, et thérapeutique: étude multicentrique rétrospective à propos de 95 cas. Gynécologie Obstétrique \& Fertilité, 43, 290-296. http://dx.doi.org/10.1016/j.gyobfe.2015.02.010

[25] Cloyd, J.M., Hernandez-Boussard, T. and Wapnir, I.L. (2013) Outcomes of Partial Mastectomy in Male Breast Cancer Patients: Analysus of SEER, 1983-2009. Annals of Surgical Oncology, 20, 1545-1550. http://dx.doi.org/10.1245/s10434-013-2918-5

[26] Giordano, S.H., Buzdar, A.U. and Hortobagyi, G.N. (2002) Breast Cancer in Men. Annals of Internal Medicine, 137, 678-687. http://dx.doi.org/10.7326/0003-4819-137-8-200210150-00013

[27] Hill, A., Yagmur, Y., Tran, K.N., Bolton, J.S., Robson, M. and Borgen, P.I. (1999) Localized Male Breast Carcinoma and Family History. Cancer, 86, 821-825. http://dx.doi.org/10.1002/(SICI)1097-0142(19990901)86:5<821::AID-CNCR18>3.0.CO;2-I

[28] Cutuli, B., Lacroze, M., Dilhuydy, J.M., Velten, M., De Lafontan, B., Marchal, C., et al. (1995) Male Breast Cancer: Results of the Treatments and Prognostic Factors in 397 Cases. European Journal of Cancer, 31A, 1960-1964. http://dx.doi.org/10.1016/0959-8049(95)00366-5

[29] Tunon de Lara, C., Goudy, G., MacGrogan, G., Durand, M., Dilhuydy, J.-M., Avril, A., Stoeckle, E., Bussieres, J.-E., Debled, M., de Mascarel, I. and Mauriac, L. (2008) Male Breast Cancer: A Review of 52 Cases Collected at the Institute Bergonie' (Bordeaux, France) from 1980 to 2004. Gynécologie Obstétrique \& Fertilité, 36, 386-394. http://dx.doi.org/10.1016/j.gyobfe.2008.02.020

[30] Sachs, M.D. (1941) Carcinoma of the Male Breast. Radiology, 37, 458-467. http://dx.doi.org/10.1148/37.4.458

[31] Stalsberg, H., Thomas, D.B., Rosenblatt, K.A., Jimenez, L.M., McTiernan, A., Stemhagen, A., et al. (1993) Histologic Types and Hormone Receptors in Breast Cancer in Men: A Population-Based Study in 282 United States Men. Cancer Causes Control, 4, 143-151. http://dx.doi.org/10.1007/BF00053155

[32] Ribeiro, G. and Swindell, R. (1992) Adjuvant Tamoxifen for Male Breast Cancer (MBC). British Journal of Cancer, 65, 252-254. http://dx.doi.org/10.1038/bjc.1992.50 
Submit or recommend next manuscript to OALib Journal and we will provide best service for you:

- Publication frequency: Monthly

- 9 subject areas of science, technology and medicine

- Fair and rigorous peer-review system

- Fast publication process

- Article promotion in various social networking sites (LinkedIn, Facebook, Twitter, etc.)

- Maximum dissemination of your research work

Submit Your Paper Online: Click Here to Submit

Or Contact service@oalib.com 